Article

\title{
Implementing nursing round to deal with unresolved nursing problem on patient with acute pain: A case report
}

\author{
Ike Nesdia Rahmawati \\ School of Nursing, Faculty of Medicine, Universitas Brawijaya, Malang, Indonesia
}

\begin{abstract}
Background: The determining factors for improvement of health services quality includes nursing services. Furthermore, a method for providing this quality nursing services is professional nursing care model, and comprises nursing round. However, fewer hospitals implement this due to several barriers including lack of knowledge and practices. This study is, therefore, aimed at identifying improvements in quality of nursing care and solving of patient's problem by frequent nursing rounds.

Design and Method: This study employed a single case report design using exploratory and descriptive methods. A 27 -year-old male underwent nephrectomy surgery to treat hydronephrosis. The person still revealed persistent pain in the surgery area even though it has been treated for 3 days. The staff nurses administered nursing round to discuss and solve this problem. The study participation was voluntary, while the involved patient gave the informed consent. The steps of nursing round procedure including preround, round, and post-round were used to solve the problem.

Results: The results indicated that nurses discovered blood clots in the patient's drain during nursing round. The cause of the persistent pain was revealed and used to determine the intervention modification needed. It was recommended to evacuate the blood clot and followed by appropriate pain management. Furthermore, the problem in the patient with acute pain was resolved.

Conclusions: This study reveals the effectiveness of regular nursing rounds to enhance the outcome of nursing care and indirectly shows an increase in quality of nursing services provided. Therefore, to optimize nursing rounds, the commitment of the nursing management is significant.
\end{abstract}

\section{Introduction}

Nurses are a dominant number among the health profession (55-65\%), providing constant and continuous 24-hour service to patients and are therefore, the most important human resource in the hospital. ${ }^{1}$ Furthermore, nursing services is a determining factor for improving health services and the quality. ${ }^{2}$ with methods including professional nursing care model comprised of nursing round. ${ }^{3}$ Nursing rounds aim at addressing problems by actively involving patients or families in discussions, and subsequently evaluating the results of actions performed. ${ }^{4}$ However, very few hospitals employ nursing rounds, ${ }^{5}$ and this is due to barriers including high workload, time pressure, and lack of knowledge. ${ }^{6}$

The implementation of regular nursing rounds positively impacted patient satisfaction and promoted the quality of nursing care. ${ }^{7}$ In additions, nurses grow and become trained through knowledge transfer and application of theoretical concepts to nursing practice. ${ }^{8}$ Also, the rounds involving direct interaction with patients helps to identify patient needs, conditions and the environment to support recovery and solve problems. ${ }^{9}$ This becomes an approach to improve cognitive, affective and psychomotor abilities, sensitivity and critical thinking. ${ }^{8}$ Therefore, awareness on the implementation of nursing rounds and the involvement of managers to optimize nursing care process is necessary. ${ }^{9}$

This paper aims to shows the use of nursing round to deal with problems in patients, and the effect in improving quality of care. Also, the nurses in this report were able to find methods to address the consultant's assessment and decision with regards to a particular patient, and thereby, prevent an outcome contrary to the patient's safety. This outcome contributes to the emerging critical thinking and discussions, therefore specific recommendations and strategies to improve nursing care is offered to ensure adequate resolution.

\section{Design and Methods}

The study design employed was a single case report, while the study methods were exploratory and descriptive. In addition, the nurses working at the hospital were enrolled to perform the nursing round, and the study participation was voluntary, while the patient involved gave the informed consent. The patient's data was presented in an anonymous form to maintain confidentiality. The nursing round procedure employed to resolve the case involved preround, round, and post-round steps (Figure 1).

The presence of nursing rounds positively impacted patient satisfaction, and has the potential to improve patient-nurse interactions and promote the quality of care. Furthermore, nursing round is a structured intervention providing nurses with the opportunity to identify and solve patient's needs and problems respectively. The findings on specific related problems are useful to support the evidence provided with regards to the possible benefits. This facilitates improved nurses decision-making abilities based on clinical observations and patient-centered care. 


\section{Results and Discussions}

The focus case is an excerpt from a nursing round in the ward led by a nurse unit manager. In the preround session, the team leader was assigned to the patient and therefore, principally responsible for care, monitoring the condition, preparation, and review of the care resume including assessment, diagnosis, care plan, implementation and evaluation. In the round session, all the participants comprising the nurse unit manager, team leader, another team leader, nurse consultant, and associate nurses, gathered around in the nurse station. First, the unit manager opened the round, delivered the objectives, and allowed the lead manager to present the case. Subsequently, the team leader presented the information of the patient's condition based on the care resume and highlighted the unresolved problem, and an overview is stated below.

Mr. S (27-year-old) was diagnosed with hydronephrosis post nephrectomy surgery on day-3. The patient complained of persistent pain in the surgery area (right waist) and a gradual increase. Furthermore, there was a drain attached with a minimal output of blood and used urinary catheter. Vital signs: HR 140/80 $\mathrm{mmHg}$, pulse $96 \mathrm{x} / \mathrm{min}$, temperature $36.8^{\circ} \mathrm{C}$, respiratory rate 20 $\mathrm{x} / \mathrm{min}$, heigh $155 \mathrm{~cm}$ and weight $65 \mathrm{~kg}$. Laboratory test results: Leu $19.47 \times 10^{3} \mu \mathrm{l}$, Hct $29.3 \%$, Ur $89 \mathrm{mg} / \mathrm{dl}$, Cr $8.30 \mathrm{mg} / \mathrm{dl}$, Alb 3.5 . Medications: cefotaxim 3x1g, antrain 3x1g, omeprazole 3x40 mg. The nurse has provided pain relief, but the patient was still suffering pain on a $7 / 10$ scale.

Following the discussion with the team members at the station, the team leader and participants approached the patient's bed. Subsequently, the team was introduced to the patient and family by the leader, and a reassessment of the patient's condition was done to find the problem cause. Furthermore, every team member questioned the patient to gain more information related to the pain. The nurse consultant tried to apply gentle pressure on the area of surgery, and the patient reported increasing pain. The nurse inspected the drain, indicating a minimal output, which was then assumed to be in good condition, due to the absence of severe bleeding. However, the nurse consultant observed the possibility of a blood clot blocking the drain. The team returned to the station and continued the discussion during the post-round. Subsequently, each member argued based on the validation results gained from the bedside assessment. Therefore, the physicians were

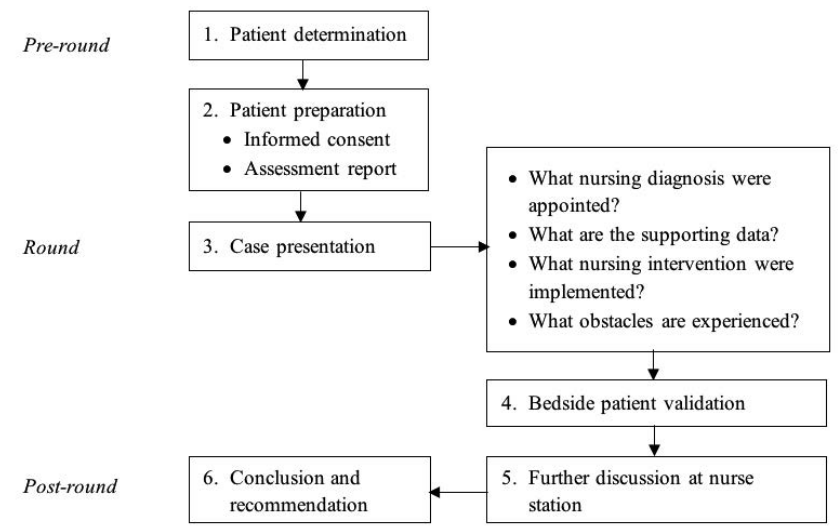

Figure 1. Nursing round steps (Adapted from Nursalam, 2020; with permission). recommended to evacuate the blood clot in the drain, which ensued smoothly with significantly reduced pain. It also followed by appropriate pain management including pharmacological and nonpharmacological therapy.

Pain is common nursing problem, and expected, after surgery. ${ }^{10}$ Severe or less severe pains may cause any medical manipulation in the body connected with the organ and tissue damage. ${ }^{11}$ Inadequately controlled postoperative pain may have harmful physiologic, psychological consequences which potentially increases the morbidity and mortality, ${ }^{12,13}$ or it may lead to chronic pain which is often misdiagnosed and neglected. ${ }^{14,15}$ In literature about the pain management in postoperational stage prevail unified standpoint that utilization of timely received and appropriate analgesic methods may give optimal analgesic level and positive result of pain management. ${ }^{16}$ Patient reported in this study also has been treated either pharmacological and nonpharmacological pain management. However, it showed no sign of improvement. In this condition, nurse should suspect something else that the patient may be dealing with. if the nurse is difficult to find answers on their own then doing a nursing round is the right way.

It was found there were blood clots inside the patient drainage. Surgical drainage is an important routine operation in surgery to drain fluid out of the body and reduce post-operative fluid collections. ${ }^{17,18}$ Inadequate surgical drainage treatment leading to blockage may result infection, worsening inflammation, slow wound formation, and increase complication. ${ }^{19}$ Therefore, if it is noticed that there is no fluid in the bulb, check the tubing for a possible blockage caused by a clot and then evacuate them.

Nursing round is an effective strategy to initiate several changes including an improvement in communication and interactions among nurse teams in discussing patient's clinical problems. ${ }^{20}$ Also, this is useful in developing clinical practice, evidence-based care, and understanding of the condition being experienced. The autonomy of nurses is therefore increased, leading to enhancement in the job satisfaction. ${ }^{21}$ Through this, nurses are involved in decision making, professional relationships with other health services, and employ evidence-based care to increase nurses' perceptions of the practice environment as a setting for professional nursing practice. ${ }^{22}$ The previous research carried out on the perception of Intensive Care nurses using nursing rounds as a care method for trauma patients influences nursing and medical management, and wound care. ${ }^{23}$ Moreover, knowledge and attitude also plays an important role during implementation. ${ }^{24}$ Previous findings revealed the impact of nursing rounds on performance in providing care. ${ }^{25}$ This skill is increased by significant training, which facilitates optimized output.

\section{Conclusions}

The result indicates the resolution of problems associated with acute pain. Patient still expressed of persistent pain in the surgery area after three days of treatment. Through nursing round, nurses indicate that the drain has stopped draining because of the formation of blood clots in the tubing. Nurses discussed this case and recommended appropriate action and the problem was solved. This proves the effectiveness of nursing rounds in enhancing the care outcome, and indirectly showed an increase in quality of services. Therefore, management commitment is highly significant in optimizing nursing rounds. 
Correspondence: Ike Nesdia Rahmawati, School of Nursing, Faculty of Medicine, Universitas Brawijaya Jl. Puncak Dieng, Kunci, Kalisongo, Kec. Dau, Malang, East Java, Indonesia 65151. Tel. +62.341569117 - Fax: +62.3241564755. E-mail: nesdia@ub.ac.id

Acknowledgment: The author is grateful to the Faculty of Medicine, Universitas Brawijaya Malang, Indonesia, for the kind support and encouragement during this study.

Key words: Nursing round; quality of care; nursing management.

Contributions: The contributions conducted by the author in this article includes the conceptualization of the study design, executing the study, data collection and interpretation, drafting and revision of the manuscript.

Conflict of interest: The author declares the absence of any potential conflicting interest.

Ethics approval: This study was approved by the Health Research Ethics Committee of the Faculty of Medicine, Universitas Brawijaya, Malang, Indonesia.

Conference presentation: Part of this study was presented at the $1^{\text {st }}$ International Nursing and Health Sciences Symposium, November $13^{\text {th }}$ to $15^{\text {th }} 2020$, Brawijaya University, Malang, Indonesia.

Received for publication: 20 January 2021.

Accepted for publication: 14 March 2021.

(Copyright: the Author(s), 2021

Licensee PAGEPress, Italy

Journal of Public Health Research 2021;10:2210

doi:10.4081/jphr.2021.2210

This work is licensed under a Creative Commons Attribution

NonCommercial 4.0 License (CC BY-NC 4.0).

\section{References}

1. Rohita T, Yetti K. [Peningkatan kualitas pelayanan keperawatan melalui ronde dan pendokumentasian (Improving the quality of nursing services through rounds and documentation)].[Article in Indonesian]. Dunia Keperawatan 2017;5:50-5.

2. Muhith A, Nursalam. [Mutu asuhan keperawatan berdasarkan analisis kinerja perawat dan kepuasan perawat dan pasien (The quality of nursing care is based on an analysis of the performance of nurses and the satisfaction of nurses and patients)].[Article in Indonesian]. J Ners 2012;7:47-55.

3. Wahyuni S, Kanang Y, Syahrul S, et al. [Penerapan Model Asuhan Keperawatan Profesional (MAKP) (Application of the professional nursing care model (MAKP)].[Article in Indonesian]. Media Karya Kesehatan 2020;3:15-26.

4. Nursalam. [Manajemen Keperawatan: Aplikasi dalam Praktik Keperawatan Profesional. Edisi 6. (Nursing management: Applications in professional nursing practice. 6th edition)].[Book in Indonesian]. Jakarta: Salemba Medika; 2020.

5. Deitrick LM, Baker K, Paxton H, et al. Hourly rounding: challenges with implementation of an evidence-based process. J Nurs Care Qual 2012;27:13-9.

6. Francis K, Kurtsev A, Walter D, et al. Nurses' experiences and perceptions of hourly rounding: A private Australian catholic hospital single case study. Int Arch Nurs Heal Care 2019;5:1-6.

7. Negarandeh R, Hooshmand Bahabadi A, et al. Impact of regular nursing rounds on patient satisfaction with nursing care. Asian Nurs
Res (Korean Soc Nurs Sci) 2014;8:282-5.

8. Sari RM, Zainaro MA. [Motivasi Perawat Dan Gaya Kepemimpinan Terhadap Ronde Keperawatan (Nurse motivation and leadership style of nursing round)].[Article in Indonesian].Holistik J Kesehat 2018;12:244-52.

9. Stella S. Optimization of nursing management rounds and implementation of discharge planning in Fatmawati Hospital Jakarta. Int J Nurs Heal Serv 2019;2:117-28.

10. Wells N, Pasero C, McCaffery M. Improving the quality of care through pain assessment and management. In: Hughes RG, editor. Patient safety and quality: An evidence-based handbook for nurses. Rockville: Agency for Healthcare Research and Quality; 2008.

11. Strode I, Seimane S, Biksane D. Pain management in nursing practice of intensive care post-operational stage patients. Int J Collab Res Intern Med Public Health 2012;4:892-900.

12. Joshi GP. Multimodal analgesia techniques and postoperative rehabilitation. Anesthesiol Clin North Am 2005;23:185-202.

13. Liu SS, Carpenter RL, Mackey DC, et al. Effects of perioperative analgesic technique on rate of recovery after colon surgery. Anesthesiology 1995;83:757-65.

14. Williams M, Milner QJW. Postoperative analgesia following renal transplantation - Current practice in the UK. Anaesthesia 2003;58:712-3.

15. Nikolajsen L, Sørensen HC, Jensen TS, et al. Chronic pain following Caesarean section. Acta Anaesthesiol Scand 2004;48:111-6.

16. Soliman HM, Mélot C, Vincent JL. Sedative and analgestic practice in the intensive care unit: The results of a European survey. Br J Anaesth 2001;87:186-92.

17. Luo K, Shi W, Chen Y, et al. A method for monitoring the working states of drainage tubes based on the principle of capacitance sensing. Sensors 2020;20:2087.

18. Ho SWL, Chua ITH. A rare case of a blood clot masquerading as a retained surgical drain. Ann Transl Med 2016;4:463.

19. Meyerson JM. A brief history of two common surgical drains. Ann Plast Surg 2016;77:4-5.

20. Fabry D. Hourly rounding: Perspectives and perceptions of the frontline nursing staff. J Nurs Manag. 2015;23:200-10.

21. Whitehead DK, Weiss SA, Tappen RM. Essentials of nursing leadership and management. Philadelpia: F.A. Davis Company; 2010.

22. Shin N, Park J. The effect of intentional nursing rounds based on the care model on patients' perceived nursing quality and their satisfaction with nursing services. Asian Nurs Res (Korean Soc Nurs Sci) 2018;12:203-8.

23. Jennings FL, Mitchell M. Intensive care nurses' perceptions of inter specialty trauma nursing rounds to improve trauma patient care - A quality improvement project. Intensive Crit Care Nurs 2017;40:35-43.

24. Agustina V, Agustian D, Ibrahim F. [Hubungan Tingkat Pengetahuan dengan Sikap Perawat dalam Pelaksanaan Ronde Keperawatan Di Ruang Aster dan ICCU RSUD dr. Doris Sylvanus (Relationship between knowledge level and attitude of nurses in implementation of nursing round in Aster room and ICCU RSUD dr. Doris Sylvanus)].[Article in Indonesian]. Din Kesehatan 2016;7:236-40.

25. Siahaan JV, Siagian A, Bukit EK. [Pengaruh Pelatihan Ronde Keperawatan Terhdap Kinerja Perawat Dalam Asuhan Keperawatan Di RS Royal Prima Medan (The effect of nursing round of training on nurse performance in nursing at Royal Prima Hospital Medan)].[Article in Indonesian]. Jumantik 2017;3:1-15. 